\title{
Peter Dronke (1934-2020)
}

El gran erudito de la poesía mediolatina y del platonismo temprano medieval Peter Dronke falleció el 19 de abril de 2020, a la edad de ochenta y seis años. Nació en Colonia en 1934, pero a partir de 1939 vivió en Nueva Zelanda, donde su familia se había refugiado para escapar de la persecución nazi (su madre era de origen judío). Tras completar sus estudios universitarios en 1955, logró una beca para el Magdalen College de Oxford; desde 1961 enseñó Literatura Latina Medieval en Cambridge, donde fue nominado fellow del Clare Hall en 1964, en 1989 obtuvo la cátedra. Emérito desde 2001, también fue miembro de la British Academy y de muchas otras instituciones académicas.

Su refinada sensibilidad para la poesía, que él atribuía sobre todo a la influencia de su madre (una actriz que había estado en contacto con T.S. Eliot), su vasta cultura literaria y musical, también arraigada en su entorno familiar, se percibe en todos sus estudios, caracterizados no sólo por una dilatada erudición que nunca se da como un fin en sí mismo, sino también por su capacidad de intuir, reconocer y desarrollar tanto el potencial conceptual de las imágenes poéticas como el alcance creativo e imaginativo de los conceptos filosóficos más atrevidos. Si la lectura de sus escritos ha sido un continuo enriquecimiento intelectual y un placer estético, colaborar con él -más de una década de experiencia en los últimos años de su vida, en años bastante avanzados de la mía- ha supuesto saborear su estilo de trabajo en un prolongado intercambio, que también me ha hecho consciente de su categoría humana, extraordinaria y espontánea.

Es posible, aunque resulte algo artificial, trazar tres líneas principales en el amplio conjunto de sus monografías y ensayos: los estudios sobre la poesía y el teatro de la Edad Media, sobre el platonismo desde Calcidio hasta el siglo XII, y los escritos sobre la era protocristiana hasta el siglo XIV. La división resulta algo artificial, porque en su visión y en sus páginas se estudian los objetos de interés individual, o más bien se contemplan con amor, con una perspectiva global, que no excluye dimensión alguna en cualquiera de sus fuentes. Necesito, sin embargo, hacer esta distinción, dado el contexto de estas páginas dedicadas a su memoria, con el fin de situar su vasta producción en una escala de creciente interés para los estudiosos de la historia de la filosofía medieval, que también corresponde a mi propio itinerario personal a través de sus páginas.

La concepción de la poesía y la individualidad poética en el medievo, desarrollada desde su primera obra extensa, Medieval Latin and the Rise of the European Love-Lyrica (1965), hasta Poetic Individuality in the Middle Ages: New Departures in Poetry, 100-1500 (1970) y Sources of Inspiration: Studies in Literary Transformation, 400 -1500 (1997), se alimenta de los motivos platónicos y neoplatónicos que constituyen el hilo conductor 
de sus investigaciones sobre los textos de la tradición filosófica. Entre las muchas profundidades de la tradición poética, me gusta recordar en particular su monografía, Dante and Medieval Latin Traditions (1986).

La centralidad misma de la individualidad poética, creativa en sentido total, está en la base de los muchos escritos de Peter Dronke sobre las figuras femeninas de la Edad Media, especialmente, pero no sólo, Eloisa y Hildegard de Bingen, que precedieron y siguieron a sus Women Writers of the Middle Ages. A Critical Study of Texts from Perpetua (†203) to Marguerite Porete († 1310) (1984). Como este título específica, los textos son el campo de investigación del erudito que, sin dejarse hechizar por lo que a principios de los años 80 podría considerarse la moda académica emergente de los estudios de género, abre el mundo interior de un pequeño y variado grupo de mujeres, cuyo testimonio escrito va desde los breves y mediatos de las cátaras de Montaillou hasta el muy extenso de Hildegard de Bingen, mientras que los temas subyacentes van desde el sueño transformador de Perpetua hasta la preocupación educativa y maternal de Dhuoda y la teología mística de Margarite Porete.

Dronke no escapa a la pregunta que era la regla de la época: «Do you think there is something about these women writers that distinguishes their work from that of men?», a lo que respondía negando que hubiese buscado la «idea platónica» de la $\mathrm{Fe}$ mininity-in-writing, sino que encontró y mostró deliberadamente la individualidad de cada una en sus diferentes formas de expresarse, contextualizándolas en su particular circunstances, sin dejar de lado algunos rasgos comunes. En particular, la motivación para escribir, raramente convencional y literaria, sino más bien vinculada a la necesidad interior de expresarse, y la falta de una postura predeterminada, en el sentido de la immediacy que las páginas de las mujeres transmiten al lector -incluso cuando se nutren de una vasta y profunda cultura que el erudito destaca.

El hecho de que el libro no fuera un homenaje extrínseco a un tema candente en el decenio de 1980 -aunque constituyese una contribución fundamental al feminismo académico, precisamente por su alejamiento de todo enfoque ideológico y la profundidad del análisis de las autoras propuestas-, lo confirma la continuidad de la investigación del autor sobre muchas de ellas. Por ejemplo, en el caso de Hildegard de Bingen, además de muchos estudios sobre aspectos específicos de sus textos, especialmente los poético-musicales, Dronke produjo la edición crítica de la obra Liber divinorum operum (1998, en colaboración con Albert Derolez). A Eloisa había regresado varias veces -en 1975 había dedicado una obra innovadora y muy bella (Francesca and Heloïse), como se muestra en la sección Heloise with and without Abelard, de la colección Intellectuals and Poets in Medieval Europe (1992); y a la edición de los Problemata Heloïse en la que estaba trabajando en el último año de su vida, habiendo dedicado un estudio a este texto ya en 1980 .

El volumen que acabo de recordar, Intellectuals and Poets, es un ejemplo particularmente significativo del caleidoscopio de temas y autores sobre los que la mente creativa y crítica de Peter Dronke ha arrojado luz en más de sesenta años de 
investigación y escritura. La primera sección, Forms of Medieval Platonism, nos introduce directamente en el campo más propiamente filosófico de sus intereses, retomando un ensayo publicado en 1969 en el Anuario de Estudios Medievales: New Approaches to the School of Chartres, y otros dos dedicados a las alegorías femeninas en la Cosmographia de Bernardo Silvestre (Dronke también realizó la edición crítica de esta obra en 1978) y al tema del integumentum en la interpretación de Virgilio aportada por Bernardo y el propio Abelardo. La relevancia filosófica del juego velo/desvelo que el uso de imágenes alegóricas permite en los poemas filosóficos pero también en los escritos en prosa -y en la relación entre los comentaristas cristianos y la cultura pagana- está en el centro de muchas obras, tanto en Fabula. Explorations into the Use of Myth in Medieval Platonism (1974), como en Imagination in the Late Pagan and Early Christian world (2002). Este último es un hermoso y muy original trabajo de investigación sobre una serie de imágenes (danza, mar, animales terrestres y celestiales, fuego, jardín) que «can be made anagogic ... employed, that is, not simply for themselves but in order to lead the human mind beyond the purely human», y por lo tanto resultan de vital importancia para penetrar profundamente en la imaginación en la que los poetas y narradores, magos y filósofos, místicos y Padres de la Iglesia se encuentran a menudo. Unos años más tarde, Forms and Imaginings: from Antiquity to the Fifteenth Century (2007) respondió a la necesidad de ampliar los términos cronológicos de este estudio, que el investigador expuso al final del primer capítulo -una introducción de profundo interés epistemológico sobre el papel cognitivo de la imaginación.

En 1988, Peter Dronke había editado un volumen para Cambridge University Press que, aunque formalmente no forma parte de la serie de Cambridge History of Philosophy, de hecho la integra al proporcionar un tratamiento preciso de la filosofía desde múltiples voces dentro del floreciente siglo del platonismo medieval, A History of TwelfthCentury Western Philosophy. Es el punto final de una tradición platónica-cristiana de la que Dronke prefiere enfatizar el carácter proteico en lugar de una continuidad lineal (The Spell of Calcidius. Platonic Concepts and Images in the Medieval West, 2008). El siglo XII, con su rica presencia de individualidad creativa en la esfera filosófica, desde los maestros de Chartres hasta Abelardo y Bernardo Silvestre, sin olvidar a Hildegard de Bingen, tal vez fuese la columna vertebral de una producción demasiado amplia para ser abordada más a fondo en estas pocas páginas. Un eje a partir del cual se han ampliado continuamente hilos de investigación en ambas direcciones temporales, sobre todo hacia la Antigüedad, llegando incluso a épocas preclásicas -como los temas órficos del huevo cósmico en Fabula, y la «cosmogonía de la risa» en el ensayo Riuso di forme e immagini antiche nella poesía (1999), ahora en Forms and Imaginings.

La amplia y fructífera dimensión de los escritos e investigaciones de Peter Dronke ha sido relatada por John Marenbon en las secciones iniciales del Festschrift dedicado a Dronke al final de su actividad como docente: Peter Dronke and Medieval Latin at Cambridge $\mathrm{y}$ "An Annotaded List of Works of Peter Dronke», en Poetry and Philosophy in the Middle Ages (2001). Pero tras esta puesta a punto hay otros veinte años de trabajo muy intenso e igualmente fructífero, incluyendo la revisión crítica del texto latino y el 
aparato de comentarios para las traducciones (en italiano) de dos gigantes del platonismo medieval: Escoto Eriúgena, cuyo Periphyseon con introducción y comentario de Peter Dronke se publicó en cinco volúmenes entre 2012 y 2017 para la Fundación Valla; y la Consolatio philosophiae de Boecio, de la que nos rindió el texto latino, la introducción y el comentario, como un precioso legado completado mientras la traducción al italiano, para el mismo editor, aún estaba en curso.

Que la majestuosa Filosofía de Boecio, junto con las muchas imágenes vivas que animan sus escritos, le haya consolado en su postrero viaje.

Michela Pereira

Università di Siena - SISMEL, Firenze 